\title{
GCU
}

Glasgow Caledonian

University

University for the Common Good

\section{Failing young people? Education and aspirations in a deprived community}

Sinclair, S.; McKendrick, J. H.; Scott, G.

Published in:

Education, Citizenship and Social Justice

DOI:

$10.1177 / 1746197909353564$

Publication date:

2010

Document Version

Author accepted manuscript

Link to publication in ResearchOnline

Citation for published version (Harvard):

Sinclair, S, McKendrick, JH \& Scott, G 2010, 'Failing young people? Education and aspirations in a deprived community', Education, Citizenship and Social Justice, vol. 5, no. 1, pp. 5-20.

https://doi.org/10.1177/1746197909353564

\section{General rights}

Copyright and moral rights for the publications made accessible in the public portal are retained by the authors and/or other copyright owners and it is a condition of accessing publications that users recognise and abide by the legal requirements associated with these rights.

Take down policy

If you believe that this document breaches copyright please view our takedown policy at https://edshare.gcu.ac.uk/id/eprint/5179 for details of how to contact us. 
Failing Young People? - Education And Aspirations In A Deprived Community

S. Sinclair, J. H, McKendrick and G. Scott 


\title{
Failing Young People? - Education And Aspirations In A Deprived Community
}

\begin{abstract}
Recent UK government statements and education policies have emphasized the need to instil a ‘culture of aspiration' among young people in deprived communities to address social exclusion. Specific proposals include raising the school leaving age to 18 and extending compulsory employment training. These statements and measures express the employment-oriented model of citizenship which underpins New Labour's approach to social justice. This paper reflects on this approach by discussing survey evidence which explored the attitudes towards education and employment among young people in a deprived community in Glasgow. These data show that the majority of these young people were ambitious regarding their post-school career paths and optimistic about their employment prospects. Emphasising the alleged low aspirations of young people in deprived communities fails to address the socio-economic conditions and opportunities which limit educational attainment and inhibit their accomplishment of full citizenship.
\end{abstract}

\section{Keywords}

aspirations, employability, social inclusion, deprivation 


\section{Introduction}

The education and training of young people has been a priority concern for the New Labour government, and there has been 'a plethora of policy developments affecting this age group' introduced since it assumed office (Bynner and Londra, 2004: 7). Of particular concern, as evident from the series of initiatives targeted towards them, are those young people perceived to be underachieving or disillusioned with the education provision intended to prepare them for the labour market (Phillips and Harper-Jones, 2003). In relation to this, there has been a recent tendency to attribute educational under-achievement among young people from disadvantaged communities to their alleged motivational deficiencies. For example, the former UK Minister of State for Employment and Welfare Reform claimed that low educational attainment in deprived communities reflected 'the near fatalistic intergenerational poverty of aspiration of the few' which contrasted with 'the almost limitless aspirations of the many' (Murphy, 2007a: 19). Recent education, training and welfare reform measures have reflected this diagnosis. For example, considerations to raise the school leaving age to 18 and 'a step change' to extend compulsory employment training for young people (Department for Work and Pensions, 2007).

Whether described as an 'underclass' expressing deviant values and a welfare burden (Gibbs, 2006; Winnet, 2005), or as socially excluded, denied opportunities and full citizenship (Dean, 1997), young people in deprived areas are certainly a priority policy concern in Scotland, which has the highest proportion of 16-19 year olds not in education, employment and training ('NEET') in the OECD (Scottish Executive, 2005a). The previous Scottish Executive's response to this issue reflected New Labour approach to social justice and education policy. For example, two of the six objectives of that Executive's social inclusion policy - Closing The Opportunity Gap (CtOG) focused respectively on enhancing and sustaining the employability of NEET young people, and improving education attainment among underachieving school pupils (Scottish Executive, nd). It is not yet apparent that the Scottish National Party minority Government elected in May 2007 has 
adopted a significantly different approach in relation to social justice and education policy from its New Labour predecessors.

This paper reflects on the beliefs and policies relating to social justice and education of the New Labour administrations in London and Edinburgh (as the latter operated between 1999-2007). It outlines and discusses survey research undertaken among young people in a severely deprived area of Glasgow. This research examined young people's orientations and expectations in relation to employment, their perceptions of their career prospects and readiness for the labour market. This evidence is used to examine two key principles of New Labour's approach to social inclusion policy: that there is a poverty of aspiration among young people in deprived areas, and that compulsion and conditionality are necessary components of employment training provision.

\section{New Labour And Social Inclusion Discourses}

New Labour and the 'third way' were developed in part to adapt social democratic politics to the demands of late modernity and globalisation (Giddens, 1998). Among the challenges which these new conditions pose is a labour market which confronts young people with 'disordered transitions' between school and independent adulthood. These changes are well documented, and include a reduction in mass semi/unskilled manual and entry level employment opportunities (particularly for lower qualified males); an increase in service employment, self-employment, and the technology and knowledge-based sectors; and an increase in flexible or insecure employment (Fenton and Dermott, 2002). Consequently, there is greater demand for 'a workforce that is mobile and flexible, with increased cultural and social capital and technical expertise', and correspondingly an increased emphasis on formal qualifications and training as a prerequisite for employment (Griffin, 2005: 295). In response to this, education policy in Britain has prioritised preparing young people 'for a 
life where changes in career path will become the norm rather than the exception' (Department for Education \& Employment, 2000).

Employment has therefore been at the heart of New Labour's education and social inclusion policies. This reflects two principles fundamental to the New Labour project. The first is empirical: the belief that employment is the most effective means of escaping poverty but that long-term structural labour market changes have reduced the employability of particular groups, especially less qualified young people. The second is normative: an ideal of social justice which emphasises individual agency and the conditionality of welfare provision.

Reflecting these principles, New Labour has promoted a model of social justice and entitlement which contrasts in important respects from that which the Labour Paryt held throughout the postwar period (Deacon, 1997). The distinguishing features of this new model, and its expression in policy, may be highlighted by considering it in relation to three alternative ideas of social exclusion discussed by Levitas (1998). The first of these is the moral underclass discourse ('MUD'), which attributes social exclusion to individual failings rather than structural disadvantage. Specifically, social exclusion is regarded as caused by the failings of a deviant underclass, marked by a subculture of negligent parenting, irresponsibility and criminality; i.e. what was once described as a 'culture of poverty' (Dean and Taylor-Gooby, 1992). This model emphasises the moral responsibilities rather than the rights of citizenship (Mead, 1986), and is reflected in 'tough love' policies such as Anti-Social Behaviour Orders, and conditional welfare entitlements, such as workfare approaches to employment training and social security eligibility.

The second model is the social integration approach ('SID'). This discourse places less emphasis on deviant subcultures and more on the barriers to employment which some groups and communities 
encounter (Ferguson, 2004). Nevertheless, it emphasises the centrality of participation in paid employment to social inclusion, and locates some of the obstacles preventing employment within excluded groups themselves rather than their social and economic circumstances (Cockburn 2002). The social rights of citizenship are perceived as conditional entitlements which must be earned by undertaking employment, training, or demonstrating efforts to enhance employability (Welsh and Parsons, 2006). This approach is reflected in education and employment training provision intended to develop human capital (Daguerre, 2007). Another example of this philosophy is the often implicit equation between old 'passive' forms of welfare provision and a culture of dependency, in contrast to new 'active' provision associated with a culture of aspiration. For example, the former Minister for Welfare Reform stated that "For years the concept of "welfare" was emblematic of collective pessimism. Now it is being turned around into something which can foster hope, aspiration, and truly transform people's lives' (Murphy, 2007b). These principles are central to the welfare reform Green Paper In Work, Better Off, which declared that social security support should be subject to claimants' responsibility 'to take up the opportunities provided by the employers' (Department for Work and Pensions, 2007: para 9). Subsequent welfare reforms, such as the Employment and Support Allowance and the Flexible New Deal, reinforce this principle of employment-conditional social citizenship.

The final model of citizenship is closer to the ideals of old rather than New Labour. This is the redistributive discourse ('RED'), which attributes poverty and social exclusion to factors beyond individual control, such as aggregate labour market demand (Davis, 2007). According to this view, those who are socially excluded are entitled to welfare support as a right of citizenship, and significant social transfers should be financed through progressive taxation.

As Cockburn observes, 'New Labour policy has shifted between these three discourses over time' (2002: 3), but Levitas (1996) is also correct in noting that much New Labour policy has favoured a 
Durkheimian or 'SID' conception of social justice, which emphasises social integration and communitarian values. Alongside this has been the tendency to express the 'MUD' discourse by attributing social exclusion and unemployment to alleged deficiencies within the groups concerned rather than to structural factors, and emphasising the conditionality of welfare benefit rights (Worth, 2005). New may be distinguished from 'old' Labour in part by its greater emphasis on personal responsibility and agency rather than structural factors as significant causes of disadvantage and social exclusion (Deacon, 2004). The recurring emphasis on the importance of raising 'aspirations' reflects the SID and MUD discourses of exclusion and social citizenship. For example, a recent report from the UK Cabinet Office Social Exclusion Task Force stated that 'Young people in certain types of neighbourhood are less likely to develop ambitious, achievable aspirations. These neighbourhoods tend to have high levels of deprivation' (2008: 2). The Minister for the Cabinet Office argued that the aspirations of these young people must be raised to prepare them for a globalised labour market (Department of Communities \& Local Government, 2009).

The previous Scottish Executive's education, employment and youth social inclusion policies shared the essential features of the UK government's approach, albeit with 'a particular Scottish flavour' in some respects (Scott, 2006: 675). This was perhaps unsurprising, given that the same New Labour party was in office in both administrations (albeit in coalition in Scotland).

A combination of assistance and enabling coupled with compulsion, correction and discipline has therefore characterised recent youth employment and social inclusion policy in both England and Scotland. It is worthwhile to reflect on the assumptions about the education and employment aspirations of young people in deprived communities which these measures express by examining the outlooks of young people themselves. The study reported here provides data relevant to explore these issues and determine whether the aspirations of young people in a deprived neighbourhood appear to be lacking. 


\section{Socio-Economic Profile Of The Study Area}

This research was conducted in a deprived community in Glasgow, a city which contains the highest concentrations of multiple deprivation in Scotland: life expectancy is considerably lower than in other areas of Scotland, compounded by high levels of alcohol and tobacco consumption, and drug abuse problems in several communities (Scottish Executive, 2005b). More generally, it is well established that young people from such deprived neighbourhoods are less likely to progress to 'positive' outcomes on leaving school. In 2007/08, 56 per cent of school leavers (from publicly funded secondary schools in Scotland) living in the 10 per cent most affluent areas in Scotland went on to Higher Education, compared to 13 per cent of those from the 10 per cent most deprived areas (the Scottish average is 31 per cent); and 21 per cent of those from the most deprived decile of areas moved on to unemployment, compared to 6 per cent of those from the least deprived decile (Scottish Government, 2008a)

The study area also contained some of the poorest performing schools in Scotland in terms of attendance, exclusions and attainment. The pupil attendance rate at one local secondary school in 2003 was 78 per cent, somewhat below the Glasgow (86 per cent) and Scotland (90 per cent) averages (Scottish Executive, 2005a: 13). Over one third of secondary school pupils did not pass English Standard Grade in 2003 compared to a national pass rate of 96.8 per cent (MacLeod, 2003). The staying-on rate at the local secondary school was 41 per cent, compared to 56 per cent in Glasgow and 65 per cent for Scotland, and only 2 per cent of school leavers entered Higher Education compared to 18 per cent for Glasgow as a whole and 32 per cent throughout Scotland. It is interesting to examine whether these disadvantages are reflected in young peoples' attitudes towards education and employment.

\section{Research Methods}


The Scottish Poverty Information Unit's Aspirations Study generated opinion data from 307 pupils in years S1 (13-14 years old) through to S6 (17-18 years old) in two schools: the only nondenominational secondary school located in the study area, and a neighbouring denominational secondary school which served the majority of the area's Roman Catholic population. The survey included a question on pupils' place of residence which permitted surveys completed by pupils living in the study area to be identified seperately from those living outside the study area. Only surveys for young people living in the study area are analysed in this paper. 229 surveys were completed by pupils attending the non-denominational school and 78 surveys were completed by pupils attending the denominational school in November 1998. Although data are not available on the number of young people living in the area who exercise a placing request, this is an issue of regional significance: 13 per cent of secondary school aged pupils resident in Glasgow attend a school outside the city (the highest exit-rate in Scotland) and 15 per cent of pupils studying in neighbouring East Dunbartonshire come from another local authority (the second highest 'external' pupil composition in Scotland) (Scottish Government, 2008b). Indeed, 314 requests were made for young people from Glasgow to be educated in East Dunbartonshire in 2007/08, of which 234 were granted (Scottish Government, 2009). As more able pupils from more deprived neighbourhoods are more likely to make a placement request, the importance of focusing on the aspirations and preparedness for employment of those young people from deprived neighbourhoods who attend their 'local' catchment school is heightened (Taylor, 2001).

Questionnaires were self-completed by pupils, without the presence of teachers but with assistance available if required from researchers. The questionnaire generated data on respondents' intentions after leaving school, employment aspirations and ideal jobs, anticipated and expected jobs, and their household and family circumstances, including household employment. Respondents were also asked to list which Common Key (CK) skills they believed they would be able to offer a prospective employer and which (if any) further skills they would like to acquire. These CK skills 
are regarded as essential foundations for employability by organisations such as the National Foundation for Educational Research and the Institute for Employment Studies.

Official school records of pupil performance, application to study and attendance were not available. However, it was possible to supplement the pupils' survey responses in the denominational school with estimates from Year Heads of pupils' application to studies, academic ability and school attendance in relation to a three point scale, ranging from 1 (minor problem) through 2 (typical for school) to 3 (major problem). These ratings provided an interesting independent estimation of pupils' overall and relative capacities in one of the two schools in the study; i.e. a total of 229 of cases, equivalent to 75 per cent of the sample population. While recognising that there were young people with attendance, achievement or application problems, Year Heads presented a more positive assessment of pupils' ability and behaviour than might appear from standard assessments of school performance. For example, Year Heads reported that three quarters of pupils had satisfactory attendance; more were 'high' achievers, than 'typical' achievers, and more were 'typical' than 'low' achievers; and the majority received a 'high' rating for application to their studies.

Without access to official school attendance records, it was not possible to be certain whether truancy introduced a potential sample bias. However, schools were asked to permit access to mixed ability classes across all school years so that the achieved sample would be representative of the school population on a typical day. Furthermore, the sample was of sufficient size to enable multivariate analyses to ascertain differences between socially participating and under- and nonparticipating pupils, and included an estimated 25 per cent of pupils in the sub-sample who, in the opinion of their Year Heads, had a major attendance problem.

\section{[Insert Table 1 here]}




\section{Learning Today And Working Towards Tomorrow}

\section{Post-School Intentions}

To explore the issue of transitions between school and the labour market, the Aspirations Study asked young people about their intentions after school and their preferred routes to employment. Respondents were asked to select from eight fixed response options which best described what they wanted to do on leaving school: 'Go to college', 'Go to university', 'Get a job', 'Join a training scheme', 'Get an apprenticeship', 'Start their own business', 'Sign on', and 'Don't know'. Of 307 responses, the majority of young people wanted to enter further education (41 per cent) or higher education (23 per cent) after leaving school; almost one sixth (15 per cent) wanted a job, while small minorities wanted to train for employment (4 per cent an apprenticeship; 6 per cent to join a training scheme), or to start their own business (4 per cent). Only 7 per cent of respondents did not know what they wanted to do, and none at all wanted to 'sign on' for unemployment benefits when they left school.

These alternative post-school destinations and preferred pathways to employment were reclassified to indicate respondents' relative levels of aspiration. To do so, responses were re-categorized as follows:

- $\quad$ High aspiration - 'Go to university', 'Start own business'

- Intermediate aspiration - 'Go to college', 'Get a job', 'Join training scheme', 'Get an apprenticeship'

- $\quad$ Low aspiration - 'Sign on' 
Starting a business was classified as a high aspiration as it indicated that the young person demonstrated qualities of initiative and entrepreneurialism, a readiness for responsibility and a desire for independence, at least in principle. In these terms, 27 per cent of respondents had high aspirations, 65 per cent intermediate level aspirations, and no respondents had low aspiration (as stated above 7 per cent responded 'Don't know'). There was a tendency for those whom Year Heads perceived to have the highest academic ability to aspire to higher levels on leaving school: two fifths of such pupils held high aspirations, compared to fewer than one quarter of those who were perceived to have less ability (see table 2).

\section{[Insert Table 2 here]}

Aspiration levels also appeared to be linked to household circumstances. 79 per cent of respondents (222 cases) indicated that at least one person in their household had a job; of these, 42 per cent of young people who lived in households with more than one adult in employment had high aspirations, compared with 26 per cent of those with only one wage earner ${ }^{1}$. This association between aspiration level and household employment is reaffirmed on further analysis and when controlling for academic ability; i.e. twice as many respondents with typical/low academic ability from households with two workers had high employment aspiration (38 per cent), compared to those of similar ability from households with only one worker (19 per cent $)^{2}$.

There were also significant variations in aspiration level between different age groups. High aspirations were reported by 37 per cent of S1/2 pupils, compared to 17 per cent of S3/4 pupils and 24 per cent of S5/6 pupils ${ }^{3}$. Although the absence of a straightforward trend may at first suggest these differences are spurious, it is more probable that young people's aspirations are lowered through secondary school (from S1/2 to S3/4). The 'recovery' of aspiration in S5/6 will reflect the 
changing school population, with those harbouring the lowest aspirations being more likely to have left school at the earliest opportunity.

Although the Aspirations Study data provides an initially positive picture of young people's aspiration to employment, there are potentially negative longer-term consequences from these findings. Clearly, the lowering of aspiration from $\mathrm{S} 1 / 2$ is worthy of further consideration. Furthermore, the increased emphasis on prior skills and qualifications in the contemporary labour market involves new risks, and a potential division in employment opportunities for young people. With the decline in traditional entry jobs, young people who enter the labour market with fewer educational qualifications or without other manifest signs of employability have considerably poorer employment prospects in the immediate and medium terms. As Bynner and Londra note, 'Polarisation is now observed among young people between those who take slower routes to adulthood and those who are precipitated onto the fast track ... Young people who are on the "fast track" to adult independence are deemed to be at greatest risk of social exclusion' (2004: 8). For example, in 2003 in Scotland, half the working population aged 25-50 without Higher grade qualifications earned less than $£ 6.50$ an hour (Palmer et al. 2004); and those with fewer skills are more likely to lose their jobs during periods of economic decline, and to experience interrupted working lives (Scott 2006). This heightens the importance of further education and training after leaving school, and to this extent, New Labour's focus on continuing preparation for employment is justified.

Aspirations Study data on post-school intentions were recast to analyse the relative directness of young people's preferred route to employment, and the extent to which they are inclined to engage in post-compulsory learning to prepare for the labour market. Consequently, the responses 'Get a job' and 'Start my own business' were classified as indicating a preference for a direct route to employment, while 'Go to college', 'Go to university', 'Get an apprenticeship' or 'Join a training scheme' were classified as preferring an indirect route to employment on leaving school. In these 
terms, four out of five young people preferred an indirect route to employment after school, while one in five wanted to go directly into jobs. While these data may not necessarily equate with the actions these young people will have taken towards their post-school destinations, nor with their actual destinations, nevertheless, they present a positive picture of post-school intentions. The results suggest that any subsequent post-school under-attainment is more attributable to some neglect in the process of preparing for demands faced after school than a lack of aspirations.

Several factors were associated with differences in young people's preferences regarding the directness of entrance to employment. The most significant of these were measures of school performance (i.e. application, academic ability and attendance), the number of skills respondents possessed and wanted to develop, and sex. Marked differences were evident between those pupils ranked favourably and less favourably by Year Heads on school performance; for example, while almost nine out of ten of those perceived to apply themselves keenly to their studies reported that they would prefer to undertake further education or training after leaving school, this fell to less than half of those whose level of application was judged to be low ${ }^{4}$. Similarly, although 59 per cent of those estimated to have low academic ability were inclined to undertake post-school education or training after leaving school, this was markedly below the 91 per cent among high ability pupils, and 70 per cent among those regarded as typical learners by Year Heads ${ }^{5}$. (A similar pattern of response was evident in relation to school attendance, with those who attended more regularly also being more inclined toward post-school education (see table 3).

\section{[Insert Table 3 here]}

The likelihood of favouring an indirect route to employment correlated both with the number of skills respondents believed they already possessed and the number which they wished to develop. The association between the number of current CK skills respondents possessed and the number they wanted to develop influences this analysis (Table 4). There is clear indication that that those 
with fewest self-perceived skills wanted to develop many: those who perceived that they possessed no skills were evenly divided across those who wanted to develop one skill (35 per cent), two skills (31 per cent) or three or more skills (34 per cent). Indeed, those who perceived that they already possessed two or more more skills were also more likely than those who perceived that they possessed no skills to want to acquire even more skills (Table 4). The overall effect of this is to confirm a relationship between both current skills and future skill development, and preferred route to employment. For example, 91 per cent of those who felt they already had between three or more skills expressed a preference for an indirect route to employment, compared with 86 per cent of those with one such skill, and 75 per cent of those who felt they possessed no skills ${ }^{6}$. Correspondingly, 86 per cent of those who wanted to develop a further three or more skills preferred an indirect route to work compared with 71 per cent of those who wanted only one?

\section{[Insert Table 4 here]}

Finally in relation to post-school intentions, while 13 per cent of girls expressed a preference for a direct route to employment, the figure for boys was 26 per cent ${ }^{8}$. This is an interesting difference in view of concerns about the relatively greater difficulties of attracting boys from deprived communities towards further and higher education in Britain (Segal, 2001; Lloyd, 2004).

To summarise, the Aspirations Study data found no evidence of any overall lack of aspirations among young people in this deprived community, nor their readiness to work. However, important attitudinal differences were apparent among them regarding the relative willingness for continuing study and training. The most important issue to address, therefore, is not a lack of aspirations among young people, but their preparedness for employment. It appears that education provision did not engage the enthusiasm of all young people nor inspire them to acquire the skills necessary for successful and sustained employment. 


\section{Ideal Jobs}

Aspirations Study respondents were asked what work they would like to do when they left school, training, college or university. This open-response question was carefully distinguished in the questionnaire from a similarly framed question asking respondents about their employment expectations - what work they thought they would do when they had completed their education. Responses were received from 290 pupils who named 32 different occupations which were then classified according to the Registrar General's 1991 schema of social classes of employment (OPCS, 1991; see also Rose, 1995) ${ }^{9}$. Young people identified a wide range of occupations, although they tended to aspire to jobs which were highly visible to the general public. There was little orientation towards prominent growth sectors in the employment market; e.g. little specific mention of work in Information Technology and, at the lower end of the labour market, no aspiration to call centre work. In terms of occupational classification, almost half of the respondents would have liked a job which was either professional (13 per cent) or managerial/technical in orientation (35 per cent); that is, classes 1 or 2 in the Registrar General's schema. Almost all of the remainder (48 per cent) aspired to skilled employment (class 3), with only 4 per cent aspiring to a partly skilled job (class 4), and no one at all identifying an unskilled job as their ideal (class 5).

The factors associated with variations in responses regarding the social status of ideal jobs were the same as those found to be significant in relation to post-school intentions; i.e. measures of school performance and the number of skills pupils possessed. For example, a majority of those who applied themselves to their studies envisaged an ideal job of higher social standing, while those of average or lower application were less likely to have high aspirations (Table 5).

\section{[ Insert Table 5 here]}


Almost half (49 per cent) of those without any attendance problems identified ideal jobs of high social standing (i.e. classes 1-2), whereas only one third (33 per cent) of those regarded by Year Heads as having attendance problems identified such jobs as their ideal ${ }^{10}$. The majority of young people (both 56 per cent) who believed they possessed no skills or only one skill had an ideal job in the class 3-5 categories (at best, a skilled job); in contrast, the majority (69 per cent) of those with two or more skills identified an ideal job of professional or managerial standing ${ }^{11}$. This relationship between current skills and ideal employment may imply that young people gain the confidence to raise their employment horizons once they have acquired increased skills. However, as the number of self-perceived skills pupils possessed was also related to their academic ability (as estimated by Year Heads), the independent influence of skill acquisition should not be overestimated.

It is not surprising that those who do not aim to enter employment directly from school are more likely to have an ideal job of higher social standing: 52 per cent of those favouring a career path with additional training or education identified ideal jobs in classes 1 or 2 , compared with 30 per cent of those who wanted to move directly into employment after leaving $\operatorname{school}^{12}$.

\section{Expected Jobs}

Respondents were asked to indicate what work they thought they would do when they left school, job training or college/university. The jobs which young people expected to get were similar to those to which they aspired. For example, 11 per cent expected to work in a professional position, 21 per cent in a managerial or technical job, 62 per cent in a skilled job, and 6 per cent in a partly skilled job. Once more, no respondents expected to work in unskilled employment. The vast majority (94 per cent) of young people in the study expected at least a skilled occupation when they entered the labour market. Compared to 'ideal' jobs, there was also a smaller proportion who expected managerial/technical occupations (class 2) and a corresponding increase in the number 
expecting skilled occupations (class 3): 48 per cent desired a manual skilled occupation, but 62 per cent expected one. However, overall it is the similarity between ideal and expected occupations that is the most striking finding: one half of young people anticipated that their future job would be their ideal job.

Morris et al. (1999: 3) observe that young people's aspirations towards work were often stereotypical, 'although they became more realistic and balanced with age.' There was some indication of this in the significant difference between the number of boys who identified 'professional footballer' as their ideal job but who did not expect to achieve this occupation, and the higher number of respondents who expected to become sales assistants after they left school. An alternative interpretation is that aspirations may be being suppressed, rather than becoming more realistic. Whatever the interpretation, there is evidence that job aspirations change through time. Whereas $41 \%$ of pupils in S1/2 expected to attain a 'higher class' job, this falls markedly to $22 \%$ by $\mathrm{S} 3$ and is sustained at this level through to $\mathrm{S} 5 / 6^{13}$.

The key factors associated with variations in young people's ideal jobs were also evident with respect to the jobs they anticipated. Thus, similar response patterns were evident for application to studies, academic ability, school attendance, number of skills possessed and anticipated route to the labour market after leaving school. Given the level of correlation between ideal and expected jobs, this repetition is unsurprising. By way of illustration: 48 per cent of those with high academic ability expected to work in a job of high social standing (classes 1-2) on leaving school, compared with only 21 per cent of those whose ability was rated 'low' by Year Heads ${ }^{14}$.

\section{Learning For Labour And Life}

The evidence indicates that despite the general difficulties of their circumstances, the young people in this deprived area remained ambitious. Most were keen to continue their education or training 
after school, aspired to jobs of high standing and were optimistic about their chances of getting the kinds of jobs they wanted. There was a shift between these domains, with more young people aspiring to better jobs, than expecting better jobs. High aspirations were also evident from young people's intended post-school career paths: a large majority looked toward post-compulsory education and training as a stepping-stone toward better employment. Very few were unsure of their preferences and none 'aspired' to a life on welfare. Although they may face problems, young people were not themselves a problem, and did not appear bound in their horizons by their locality and experiences (McKendrick et al.2007).

However, within this generally positive picture there is a potentially troubling sub-theme. One in five young people in the Aspirations Study favoured direct entry to employment without further education or training, and while this should not be equated with low aspirations per se (e.g. respondents who want to start their own businesses were regarded as having 'high' employment aspirations), nor was there evidence that young people who wanted employment immediately aspired only to low-level jobs, nevertheless there is a consistent correlation between preferring direct labour market entry and outlooks which may inadvertently contribute to longer term employment problems. Respondents who favoured direct entry to the labour market showed lower levels of application to their studies, more problematic school attendance and lower estimated academic ability. These young people also believed they currently possessed fewer CK skills but expressed no greater desire than other respondents to acquire further skills. They had generally lower ambitions and expectations for employment. In short, a preference for entering the labour market immediately after leaving school appears associated with lower employment horizons. Nevertheless, these lower aspirations did not mean that they rejected the work ethic nor were resigned to a life of welfare dependency.

Those who expressed a preference for an immediate job were not a strata distinguished by their socio-economic characteristics nor household circumstances, but rather by their attitudes and 
dispositions. Nevertheless, there are two inter-related issues associated with direct labour market entry which are likely to create future problems for these young people. Firstly, in the short term, young people who enter employment directly upon leaving school without further education or training are more likely to be disappointed with their jobs and immediate experiences of employment. As Bynner (2001: 13) notes, ‘A striking feature of British youth's headlong rush towards the labour market is their positive evaluations of their own achievements and prospects'. However these high estimations and expectations are not generally shared by employers (Stewart, 2006). The outcome of this disjuncture between beliefs, expectations and the reality of low grade entry-level jobs is to heighten the level of employment churn among less qualified young workers.

This leads to the second medium to longer term problem of direct labour market entry: the increased risk of a fragmented working life and the problems associated with this. As employment prospects have become increasingly tied to formal education and training qualifications, so evidence of labour market polarisation between those with and without these attributes has grown (Kemp et al. 2004). More optimistic theories have speculated that a high level of job turnover was evidence of the increasing freedom of skilled 'portfolio' career professionals. However, in reality job churn and fractured employment trajectories are associated with lower income employment among less qualified workers (Fenton and Dermott, 2002). Frequent job changes are primarily an indication of insecurity and dissatisfaction with a succession of low skilled and unrewarding low paid jobs among the least advantaged in the labour market (Worth, 2005). Consequently, those entering the labour market directly with few qualifications are more likely to be disadvantaged by discontinuous employment and more vulnerable to the problems of fragmented working lives, such as lower income, less access to occupational welfare benefits and fewer prospects for progression (Ginn and Arber, 1993; Burton, 1997). It may not be immediately apparent to young people who want to start their working lives at the earliest opportunity that they may be disadvantaging themselves in the longer term, but they quickly realise this when their circumstances change and they begin to assume more adult responsibilities, such as dependent children (Smith, 2000). 
Unfortunately, by then it may be too late, or considerably more difficult, to acquire the qualifications and skills necessary for sustainable employment and career progression. The desire among a sizeable minority of young people in the Aspirations Study to enter the labour market at the earliest opportunity is therefore not a positive sign of maturity, but rather an indication of likely future employment problems and heightened risk of social exclusion.

Employment is an important and successful means of escaping poverty for many, but it does not in itself guarantee protection against poverty or social exclusion. There is evidence that many less skilled and lower qualified workers are caught in a 'low pay, no pay' cycle of insecure and unrewarding jobs interspersed with periods of unemployment (Kemp et al. 2004). The implications of this, and the findings of the Aspirations Study, for UK social inclusion, education and employability policies are to reinforce the significance of stability and progression in employment 'to sustain individuals or families in a lifestyle free from poverty' (Scottish Executive, nd). Policy must look beyond moving unemployed people into jobs, and consider the longer-term challenge of ensuring that "vulnerable members of the labour market are not left in a churning trap between bottom-end jobs and unemployment' (Worth, 2005: 410). In relation to younger people, the challenge facing education and employability policy is to develop provision which will encourage less ambitious school leavers to think beyond their immediate entry to the labour market and prepare for the challenges they will face throughout the rest of their working lives. This requires both young people and policy makers to invest for the future rather than be swayed by the attraction of short-term goals and immediate results.

It is therefore appropriate for the UK and Scottish governments to emphasise the importance of and rights to post-school education and training, as this contributes towards longer term employment stability. Encouraging young people to undertake continuing education or training is potentially beneficial, even if it entails extending the transition to independent adulthood in the short term. However, while the intentions of government policy may be correct, the Aspirations Study data 
suggests that they are pushing at an open door, and that there is no need to use threats nor coercion when young people themselves express such high aspirations. Rather, it would be better to work with and build upon young people's post-school aspirations. As Fletcher et al (2007: 3) observe 'if voluntary measures increase participation significantly then bringing in systems of enforcement ... could be a sledgehammer to crack a nut'.

\section{Conclusions}

At the aggregate level, the odds are stacked against young people in deprived communities; however the Aspirations Study found no evidence of any deficiency in terms of their motivation, aspirations nor willingness to work; there was no sign that these young people were part of a deviant 'moral underclass'. Despite their disadvantaged circumstances, most of these young people were ambitious and had high expectations; they were neither discouraged nor cynical about the opportunity gap they faced.

The challenge confronting UK education policy is therefore not that of re-engaging a disaffected generation of young people from deprived areas, but the more subtle and demanding task of dealing with the consequences a minority of young people not aiming high enough, who are only too willing to work but whose readiness to do so is not matched by their preparedness and skills, and who are therefore likely to be vulnerable in a labour market which requires increasing flexibility and skills. To enable citizenship for young people in deprived areas, it is not necessary to push them into jobs; achieving social inclusion through social integration requires capitalising on the aspirations which they evidently possess, and matching their evident desire to work with appropriate employment opportunities. This requires making education something which is attractive to young people in deprived neighbourhoods and demonstrating that schools are valuable in helping them to reach the status to which they aspire. 
Failing Young People? - Education And Aspirations In A Deprived Community 


\section{Notes}

Chi-square 6.43; Statistically significant 0.011; No cells have an Expected Frequency of less than five).

Chi-square 3.8; Statistically significant 0.051 ; No cells have an Expected Frequency of less than five.

Chi-square 10.26; Statistically significant 0.006; Only one cell has an Expected Frequency of less than five [16.7\%].

$4 \quad$ Chi-square 23.130; Statistically significant 0.000; No cells have an Expected Frequency of less than five.

$5 \quad$ Chi-square 18.701; Statistically significant 0.000; No cells have an Expected Frequency of less than five.

$6 \quad$ Chi-square 6.778; Statistically significant 0.034; No cells have an Expected Frequency of less than five.

7 Chi-square 6.953; Statistically significant 0.031; No cells have an Expected Frequency of less than five.

$8 \quad$ Chi-square 7.982; Statistically significant 0.005; No cells have an Expected Frequency of less than five.

9. Some occupations were described with insufficient detail to enable their social class to be estimated. Generally, these 'lowered' the overall occupational class profile, as data on expected supervisory responsibilities (an important factor in the Registrar General's occupational class groupings) tended not to be provided. Chi-square 3.92; Statistically significant 0.048 ; No cells have an Expected Frequency of less than five.

Chi-square 8.441; Statistically significant 0.015 ; No cells have an Expected Frequency of less than five.

Chi-square 7.936; Statistically significant 0.005 ; No cells have an Expected Frequency of less than five.

Chi-square 6.692; Statistically significant 0.035; Only one cell has an Expected Frequency of less than five $(16.7 \%)$.

Chi-square 6.731; Statistically significant 0.035; No cells have an Expected Frequency of less than five. 


\section{References}

Burton, D. (1997) Ethnicity and occupational welfare: a study of pension scheme membership in Britain. Work, Employment \& Society, 11 (3), 505-518.

Bynner, J. (2001) British youth transitions in comparative perspective. Journal Of Youth Studies, 4 (1), 5-23.

Bynner, J. \& Londra, M. (2004) The Impact Of Government Policy On Social Exclusion Among Young People. London: Office of the Deputy Prime Minister / Social Exclusion Unit.

Cabinet Office Social Exclusion Task Force. (2008). Aspiration And Attainment Amongst Young People In Deprived Communities - Analysis And Discussion Paper. (December.). http://www.cabinetoffice.gov.uk/media/109339/aspirations_evidence_pack.pdf

Cockburn, T. (2002). Concepts of social inclusion / exclusion and childhoods. Paper presented to Challenging 'Social Inclusion': Perspectives for and from Children and Young People. Edinburgh, $4^{\text {th }}-6^{\text {th }}$ December.

Daguerre, A. (2007) Active Labour Market Policies And Welfare Reform: Europe And The US In Comparative Perspective. Basingstoke: Palgrave.

Davis, J. M. (2007) Analysing participation and social exclusion with children and young people. lessons from practice. International Journal of Children's Rights. 15 (1), 121-146.

Deacon, A. (1997). Lawrence Mead and the new politics of welfare. In Mead, L. \& Field, F. (eds). From Welfare To Work: Lessons From America. London: Institute of Economic Affairs, xiixvi.

Deacon, A. (2004). Review article - different interpretations of agency within welfare debates. Social Policy \& Society, 4 (4), 447-455.

Dean, H. (1997) Underclassed or undermined? Young people and social citizenship. In MacDonald, R. (ed). Youth, The 'Underclass' And Social Exclusion. London: Routledge, 55-69. 
Dean, H. \& Taylor-Gooby, P. (1992) Dependency Culture: The Explosion Of A Myth. Hemel Hempstead: Harvester Wheatsheaf.

Department for Education and Employment (2000) Preparing pupils for a successful future in learning and work. London: HMSO. http://www.dfes.gov.uk/publications/guidanceonthelaw/dfeepub/schoolpub/careers.shtml [accessed 24 $4^{\text {th }}$ July 2006].

Department for Work and Pensions (2007) In Work, Better Off: Next Steps To Full Employment. (Cm 7130). London: Department for Work and Pensions.

Department of Communities \& Local Government. (2009). A Bigger Role For Communities In Inspiring Young People. Press Release, $8^{\text {th }}$ April.

Fenton, S. \& Dermott, E. (2002) Fragmented careers? Winners and losers in young adult labour markets. Work, Employment And Society, 20 (2), 205-221.

Ferguson, R. (2004) Discourses of exclusion: reconceptualising participation amongst young people. Journal Of Social Policy, 32 (2), 289-320.

Fletcher, M, Corney, M. \& Stanton, G. (2007). Raising The Leaving Age To 18: Symbol Or Substance? Reading: CfBT Education Trust.

Giddens, A. (1998) The Third Way: The Renewal of Social Democracy. Cambridge: Polity.

Ginn, J. \& Arber, S. (1993) Penalties: the gendered division of occupational welfare. Work, Employment \& Society, 7 (1), 47-70.

Griffin, C. (2005) Whatever happened to the (Likely) Lads? - 'Learning To Labour' 25 years on. British Journal of Sociology of Education, 26 (2), 291-297.

Kemp, P, Bradshaw, J, Dornan, P, Finch, N. \& Mayhew, E. (2004) Routes Out Of Poverty. York: Joseph Rowntree Foundation.

Levitas, R. (1996) The concept of social exclusion and the new Durkheimian hegemony. Critical Social Policy, 16 (46), 5-20.

Levitas, R. (1998). The Inclusive Society?: Social Exclusion And New Labour. London. 
Lloyd, T. (2004) Preparing underachieving young men for the workplace. Local Economy, 19 (3), 288-291.

MacDonald, R. \& Marsh, J. (2004) Missing school: educational engagement, youth transitions, and social exclusion. Youth \& Society, 36 (2), 143-162.

$M^{c}$ Kendrick, J.H. Scott G. \& Sinclair, S. (2007). 'Dismissing Disaffection: Young People's Attitudes Towards Education, Employment And Participation In A Deprived Community'. Journal of Youth Studies. 10 (2), 139-161.

MacLeod, D. (2003) Highers meet the standard in Scotland. The Guardian, $12^{\text {th }}$ August.

Mead, L. (1986) Beyond Entitlement: The Social Obligations of Citizenship. New York: The Free Press.

Morris, M, Nelson, J, Richardson, M, Stoney, S.M. with Benefield, P. (1999) A Literature Review Of Young People's Attitudes Towards Education, Employment And Training. London: DfEE, Research Brief No’ 170.

Murphy, J. (2007a) Progressive self-interest - the politics of poverty and aspiration. In Rossiter, A. et al (eds). The Politics of Aspiration. London: Social Market Foundation.

Murphy, J. (2007b) Welfare reform - challenges for the next 10 years. Speech $12^{\text {th }}$ Feb. http://www.dwp.gov.uk/aboutus/2007/12-02-07.asp [accessed 15 ${ }^{\text {th }}$ May 2009].

OPCS (1991) Standard Occupational Classification Volume 3. London: HMSO.

Palmer, G., Carr, J. \& Kenway, P. (2004) Monitoring Poverty And Social Exclusion In Scotland 2004. London: Joseph Rowntree Foundation / New Policy Institute.

Phillips, R. \& Harper-Jones, G. (2003) Thematic review - Whatever next? Education policy and New Labour: the first four years, 1997-2001. British Educational Research Journal, 29 (1), $125-132$.

Registrar General (1991) Social Class Based On Employment Schemata. London: Office of Population Census and Surveys.

Rose, D. (1995) Official social classifications in the UK, Social research update, 9. (July). http://www.soc.surrey.ac.uk/sru/SRU9.html 
Scott, G. (2006), Active labour market policy and the reduction of poverty in the 'new' Scotland. Critical Social Policy, 26 (3), 669-684.

Scottish Executive (nd), Closing the Opportunity Gap - Anti Poverty Framework, http://www.scotland.gov.uk/Topics/People/Social-Inclusion/poverty/17415-1 [accessed $11^{\text {th }}$ May 2009].

Scottish Executive. (2005a) Employability Framework For Scotland: Report Of The NEET Workstream. Edinburgh: Scottish Executive.

Scottish Executive. (2005b) Social Focus On Deprived Areas, News Release. http://www.scotland.gov.uk/News/Releases/2005/09/27111219 [accessed $21^{\text {st }}$ October 2007]. Scottish Government. (2008a) National and Local Authority Information On The Destinations Of Leavers From Publicly Funded Scottish Secondary Schools: 2007/08. Education Series Statistical Bulletin Edinburgh: Scottish Government.

Scottish Government. (2008b) Pupils In Scotland 2007. Education Series Statistical Bulletin Edn/B1/2008/1. Edinburgh: Scottish Government.

Scottish Government. (2009) Placing Requests in Schools in Scotland 2007/08. Education Series Statistical Bulletin Edinburgh: Scottish Government.

Segal, L. (2001) Academics will be boys. The Guardian, $16^{\text {th }}$ January.

Smith, D. (2000) Dealed out? Welfare to work and social exclusion. Local Economy, 15 (4), 312324.

Stewart, H. (2006) So far, migrant workers have been just the job. The Observer, $27^{\text {th }}$ August. Taylor C, (2001) Geography of the 'New' Education Market: Secondary School Choice in England and Wales. Aldershot: Ashgate.

Welsh, P. J. \& Parsons, C. (2006) Social justice, service delivery and welfare reform: the politics of deprivation, disaffection and education in the District of Thanet. Education, Citizenship and Social Justice, 1 (1), 39-57.

Winnet, R. (2005) Meet the "NEETs": a new underclass. The Sunday Times, $27^{\text {th }}$ March. 
Failing Young People? - Education And Aspirations In A Deprived Community

Worth, S. (2005) Beating the 'churning' trap in the youth labour market. Work, Employment And Society, 19 (2), 403-413. 


\section{Tables}

Table 1: Education characteristics of Aspirations Study pupils (Column \%)

Estimated attendance ${ }^{1}$

Typical

74

Minor problem

16

Major problem

11

Cases $\quad 230$

Estimated academic ability ${ }^{1}$

High

44

Typical (school average)

37

Low

19

Cases

Estimated application to studies ${ }^{1} \quad$ High

Typical (school average)

Low

Self-perceived number of CK

Two-seven

skills possessed (denominational

school only)

One

None

47 
Self-perceived number of CK Two-seven 12

skills possessed (non-

denominational school only)

One

None
27

61

Cases $\quad 74$

\section{Source: SPIU Aspirations Study}

Notes (1) Denominational school only. (2) Percentages do not always not sum to $100 \%$ due to rounding. (3) The differences in self-perception of skills between pupils in the denominational and the nondenominational school are statistically significant at the $95 \%$ confidence level (Chi-square $=6.154$; Statistical Significance $=0.046$; No cells with an Expected Frequency of less than 5) 
Failing Young People? - Education And Aspirations In A Deprived Community

Table 2: Aspiration Levels, by Estimated Academic Ability (Row \%)

Employment aspiration level

Academic ability $^{1}$

High Intermediate Cases

High

40

60

96

Not high

24

77

115

Base: 211

Source: SPIU Aspirations Study (non-denominational school only)

Notes (1) Typical' and 'low' categories of academic ability have been combined into a single 'not high' category. (2) Row percentages do not always not sum to $100 \%$ due to rounding. (3) The differences are statistically significant at the 95\% confidence level (Chi-square $=6.367$; Statistical Significance $=0.012$; No cells with an Expected Frequency of less than 5. 
Table 3: Directness of Route to Employment, by Estimated Application to Studies and School Attendance $(\text { Row \%) })^{1}$

Preferred route to employment

Application to studies

Indirect

Direct

Cases

$\begin{array}{rccc}\text { High } & 88 & 12 & 124 \\ \text { Typical (school) } & 70 & 30 & 60 \\ \text { Low } & 48 & 52 & 27\end{array}$

School attendance ${ }^{3}$

$$
\text { Typical }
$$

Minor problem

Major problem
84

63

55
16

160

37

30

46

Source: SPIU Aspirations Study (non-denominational school only)

Notes (1) Row percentages do not always not sum to $100 \%$ due to rounding. (2) The differences for application to studies are statistically significant at the 95\% confidence level (Chi-square $=23.130$; Statistical Significance $=0.000$; No cells with an Expected Frequency of less than 5). (2) The differences for school attendance are statistically significant at the $95 \%$ confidence level (Chi-square $=13.816$; Statistical Significance $=0.001$; Only one cell has an Expected Frequency of less than 5 [16.7\% of all cells]). 
Table 4: Number of CK Skills Respondent Wished to Develop, by Number of Existing Skills (Row \%)

Number of CK skills respondent

wished to develop

\begin{tabular}{rccccc} 
Number of CK skills possessed & Three- & Two & One & Cases \\
& & Seven & & & \\
Two-Seven & 30 & 48 & 23 & 44 \\
\hline One & 49 & 25 & 26 & 81 \\
None & 34 & 31 & 35 & 166
\end{tabular}

Base: 291

Source: SPIU Aspirations Study (both schools surveyed)

Notes: (1) Row percentages do not always not sum to $100 \%$ due to rounding. (2) The differences are statistically significant at the 95\% confidence level (Chi-square $=11.7$; Statistical Significance $=0.020$; No cells with an Expected Frequency of less than 5. 
Table 5: Occupational Class of Respondent's Ideal Jobs, by Estimated Application To Studies

Social class of ideal job

\begin{tabular}{rrrrr}
\hline Application to studies & Classes 1-2 & Classes 3-5 & Cases \\
& High & 54 & 46 & 112 \\
Typical (school) & 35 & 65 & 51 \\
Low & 29 & 71 & 28 \\
\hline
\end{tabular}

Base: 191

Source: SPIU Aspirations Study (non-denominational school only)

Note: The differences are statistically significant at the 95\% confidence level (Chi-square $=8.318$; Statistical

Significance $=0.016$; No cells with an Expected Frequency of less than 5. 